\title{
Causes of uncertainty in observed and projected heterotrophic respiration from Earth System Models
}

Cary Lynch ${ }^{1}$, Corinne Hartin ${ }^{1}$, Min Chen ${ }^{1}$, and Ben Bond-Lamberty ${ }^{1}$

${ }^{1}$ Pacific Northwest National Laboratory, Joint Global Change Research Institute, 5825

University Research Court, Suite 3500, College Park, MD 20740

Correspondence to: Cary Lynch (cary.lynch@pnnl.gov)

\begin{abstract}
Heterotrophic respiration ( $\mathrm{RH})$ is a large component of the terrestrial carbon cycle, but one poorly simulated by Earth system models (ESMs), which diverge significantly in 15 their historical and future RH projections. There is little understanding, however, of the causes of this variability and its consequences for future model development and scenario evaluation, and examining the relationships between RH and key climate variables may help to understand where and why models are divergent. We quantified the statistical relationships between $\mathrm{RH}$ and other terrestrial/climate variables across a suite of 25

20 ESMs from the Coupled Model Intercomparison Project phase 5 (CMIP5) for the $20^{\text {th }}$ and $21^{\text {st }}$ centuries, comparing the models both to each other and to an observation-driven global RH dataset. Compared to observations, ESMs consistency overestimate both the magnitude and climate sensitivity of global RH. The relationship between RH and surface air temperature (TAS) is strong, especially at high latitudes, and largely

25 consistent across models. The observed RH and precipitation (PR) relationship is strong and positive $(r \geq 0.5, \mathrm{P}<0.005)$, but few models consistently show this sensitivity of RH to PR. The RH-TAS relationship explored here, and more pattern scaling methods more generally, can be used to efficiently explore uncertainty and projected changes in $\mathrm{RH}$ under a wide range of future emission scenarios, and understand how models' structural

30 and parametric choices produce divergent results. Because uncertainty in RH has large effects on ESM projections of future climate, this may help direct attention to relationships in the carbon cycle that contribute to this uncertainty.
\end{abstract}

\section{Introduction}

Soil heterotrophic respiration $(\mathrm{RH})$, the soil-to-atmosphere $\mathrm{CO}_{2}$ flux derived from microorganisms' metabolism of litter detritus and organic carbon, constitutes a large and highly uncertain component of the terrestrial carbon cycle (Hashimoto, 2012; Hashimoto et al., 2015; Luo and Zhou, 2006). This carbon flux may result in a significant climate

40 feedback in the future, as mineralization of long-stored soil carbon releases $\mathrm{C}$ to the atmosphere (Bond-Lamberty and Thomson, 2010b; Friedlingstein et al., 2014). This will be dependent on how strongly large-scale processes, including RH, are affected by abiotic drivers such as temperature and precipitation (Bond-Lamberty and Thomson, 2010b; Hursh et al., 2016; Sierra et al., 2015). While both temperature and precipitation 45 have a positive effect on the global terrestrial carbon flux (Li et al., 2017; Liu et al., 2016), the effect of these drivers can change in complex ways depending on the spatial 
Earth System Models (ESMs) generally project increases in the RH flux due to global climate change (Friedlingstein et al., 2014). However, RH model structure and

5 parameterizations are quite simple relative to many other processes (Wieder et al., 2013): RH is typically treated as a first-order decay process occurring in litter and distinct soil layers, with remaining leaf litter and woody debris ultimately transported to the belowground carbon pool after fire losses (Shao et al., 2013). As a result, ESMs generally do not accurately capture either the observed RH flux (Shao et al., 2013) or the spatial 10 distribution of soil carbon (Todd-Brown et al., 2013). At the global scale net primary production (NPP) and RH are of roughly equal magnitude (Hashimoto, 2012; Zhao and Running, 2010), and interestingly, ESMs appear to better capture the observed NPP flux (Todd-Brown et al., 2013). This discrepancy between NPP and RH would suggest that there is large model uncertainty in RH quantification, and this uncertainty can have large effects on ESM predictions of the $21^{\text {st }}$ century Earth system (Friedlingstein et al., 2014).

Thus, it is important to understand and explore the uncertainty in RH quantification. Pattern scaling, one technique for doing so, can be used to examine key relationships between RH and abiotic drivers such as surface air temperature (TAS), as well as carbon

20 fluxes such as NPP. In pattern scaling, a 'pattern' is the relationship between a local and global variable, and is intended to provide a measure of local sensitivity to global change (Mitchell, 2003; Osborn, 2009; Santer et al., 1990). These patterns can then be scaled in magnitude by a specified global mean RH, NPP, or TAS change obtained from a simple climate model (SCM). It is a simple, flexible approach that allows for a computationally

25 efficient analysis of a wide range of future scenarios that have not been simulated by ESMs. Pattern scaling may help to understand why certain models show a larger future trend than others by examining the relationships between $\mathrm{RH}$ and other variables, and comparing model output to observed data.

30 In this study, we analyzed historical RH from an ensemble of ESMs and compared these outputs to an observation-based data product. Then we examined the statistical uncertainty of projected RH across models and projections, and explored the spatial and temporal relationships between RH and other variables. Finally, we investigated whether pattern scaling can be used to better quantify changes and uncertainty in projected $\mathrm{RH}$,

35 and understand the characteristics, strengths, and weaknesses of different ESMs with respect to $\mathrm{RH}$ and the terrestrial carbon cycle.

\section{Methods}

\subsection{Datasets}

Table 1 lists the observed datasets used to evaluate ESM RH outputs. The Hashimoto et al. (2015) soil respiration (RS) data include an annual gridded RH product created by assimilating observed RS into a statistical model to achieve continuous spatial and

45 temporal coverage for the $20^{\text {th }}$ and early $21^{\text {st }}$ centuries (Hashimoto et al., 2015);(Hashimoto et al., 2015)RH is then computed based on a simple empirical 
relationship (Bond-Lamberty et al., 2004). RH changes over time in this dataset, but these changes are driven entirely by climate and do not include process- or land-use based changes in the carbon cycle. Currently, because RH cannot be directly measured at scales larger than a few square meters (Bond-Lamberty et al., 2016), the Hashimoto et al. (2015) dataset is the best available estimate of both the spatial distribution and global total RH flux (Xu and Shang, 2016).

Other observation/reanalysis datasets used include monthly NCEP TAS (Kalnay et al., 1996) and NASA precipitation flux (PR; Adler et al., 2003) reanalysis products; and an annual NPP, satellite derived product (Zhao et al., 2005).

We used model output from two sets of experiments from the Coupled Model Intercomparison Project Phase 5 (CMIP5; Taylor et al., 2012). The 'historical' experiment was used to evaluate model performance metric as compared to observations.

15 Model historical runs varied in length, so we used 1901 as the start of the historical period, and 2005 as the end. For future projections, we used the high-forcing RCP 8.5 scenario, in which radiative forcing increases to $8.5 \mathrm{~W} / \mathrm{m}^{2}$ in 2100 (Riahi et al., 2011). For the future simulations, the start year was 2006, and the end year was 2099.

20 For the assessment of patterns, we used all available climate models, resulting in an ensemble of 25 ESMs (Table 2), and we only used the first realization (i.e., ensemble member) from each model. No performance weights were constructed, and the assumption of model independence was implicit.

25 Most of the analysis was limited to the area between $80^{\circ} \mathrm{N}$ and $60^{\circ} \mathrm{S}$. All observed and model output was regridded to the lowest spatial resolution $\left(2.8^{\circ}\right.$ by $\left.2.8^{\circ}\right)$ of the multimodel ensemble prior to the calculation of an ensemble mean. This was done for averaging purposes, as each model had a different spatial resolution. Regridding to the lowest resolution of the multi-model ensemble is a conservative assumption that avoids

30 interpolation errors.

\subsubsection{Pattern scaling}

Pattern scaling (Santer et al., 1990) was used to estimate statistical relationships between local (subscript L) and global mean/total (subscript G) climate variables. Here, a least square regression (LSR) approach was used (Kravitz et al., 2017; Lynch et al., 2017) in which patterns were calculated from the RCP 8.5 future forcing scenario for all models as:

$\mathrm{Y}_{\mathrm{L}}=\alpha+\beta * \mathrm{X}_{\mathrm{G}}+\varepsilon$

In this equation, $X_{G}$ is the global annual mean (TAS) or total (RH, PR, NPP) climate predictor (one-dimensional, unsmoothed), and $\mathrm{Y}_{\mathrm{L}}$ is the gridded local climate dependent variable (three dimensional). $\beta$ is a two-dimensional field of regression slopes, and $\varepsilon$ is a

45 three-dimensional residual term (error) stemming from linearly fitting the dependent variable to the predictor. $\alpha$ is the y-intercept, which we take to be 0 by only computing 
change, not absolute values. Calculated patterns are described in terms of 'sensitivity', i.e. amount of local, grid-cell change per 1 unit global change.

To evaluate pattern accuracy, we quantified the differences between the reconstruction

5 B and the actual model output B via the root mean square error (RMSE) over the areaweighted difference at the end of the $21^{\text {st }}$ century. In this instance RMSE is used to describe how well the predicted pattern emulates the actual model change, with lower RMSE indicating that the predicted pattern better captures the actual model change.

$R M S E=\frac{\sqrt{\sum_{x}[(\hat{B}(x)-B(x)) \cdot A(x)]^{2}}}{\sqrt{\sum_{x}[A(x)]^{2}}}$

where $A(x)$ is the area of the grid box $x$ and sums were calculated over all $x$.

\section{Results}

\subsection{Observed trends and relationships}

Most models do not capture the magnitude or trend of observed annual global RH (Figure 1, and Supplementary Figure 1). The 25 CMIP5 models examined exhibited increasing

20 RH throughout the historical and future periods, from a mean of 60 (range of 45-83) Pg C $\mathrm{yr}^{-1}$ in 1901 to 90 (range of 57-139) $\mathrm{Pg} \mathrm{C} \mathrm{yr}^{-1}$ by the end of the $21^{\text {st }}$ century. In contrast, observed data support a best estimate of $51 \mathrm{Pg} \mathrm{C} \mathrm{yr}^{-1}$ in 1901 and only $52 \mathrm{Pg} \mathrm{C} \mathrm{yr}^{-1}$ in 2013. Most models thus overestimate, by about $8 \mathrm{Pg} \mathrm{C} \mathrm{yr}^{-1}$, global RH as compared to our best statistical upscaling estimate of global RH. In the observed period the

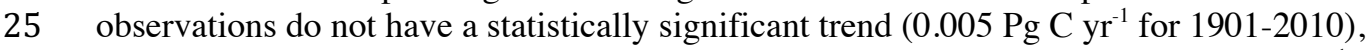
but the majority of the climate models have a slight positive trend ( 0.02 to $0.1 \mathrm{Pg} \mathrm{C} \mathrm{yr}^{-1}$ for 1901-2005).

Under the RCP 8.5 forcing scenario, the projected trend is strongly positive ( 0.06 to 0.6

$30 \mathrm{Pg} \mathrm{C} \mathrm{yr}^{-1}$ for the $21^{\text {st }}$ century) and the model spread is larger than it is in the historical period. The HadGEM models project the largest $21^{\text {st }}$ century change in global $\mathrm{RH}$, while the NorESM models project the smallest change (Supplementary Figure 1), which is consistent with NPP results from Todd-Brown et al (2014).

35 Models vary in their estimation of interannual standard deviation (Figure 2). Even though the historical interannual standard deviation is relatively large for some models, it stays constant for much of the $20^{\text {th }}$ century. Models from the same modeling center are very similar in their projected trends in standard deviation. In the future, the interannual standard deviation of $\mathrm{RH}$ is projected to change from a mean of $0.98 \mathrm{Pg} \mathrm{C}$ in 1900 to 1.35

$40 \mathrm{Pg} \mathrm{C}$ in 2100 (Figure 2). The majority (65\%) of the models show an increase in interannual variability, but some project standard deviation to stay the same (CCSM4/CESM) or even decrease (GISS-E2 and NorESM) by the last half of the $21^{\text {st }}$ century. The models with the lowest (or decreasing) interannual standard deviation are 
also the models with the smallest projected trend (Supplementary Figure 1).

The individual models exhibit significant differences in correlation, bias, and error (Figure 3). The majority of the models in the ensemble had a positive bias, and the average positive bias was larger than the negative bias. The MPI models (22-23) had the largest positive bias and the CCSM4-CESM models (5-8) had the largest negative bias. The MIROC models (20-21) had the smallest bias overall. The MPI models (22-23) had the largest spatial correlation values, and the IPSL models (17-19) had the smallest spatial correlation values. The GISS-E2 models (11-14) had the lowest RMS differences, while the HadGEM models (15-16) had the highest RMS differences. For both simple metrics of historical performance, models from the same modeling center had similar bias and spatial correlation magnitudes.

The modeled and observed relationship between RH and surface temperature (TAS)

15 exhibit latitudinal patterns (Figure 4a and Supplementary Figure 2a). Correlation values are greater at high latitudes, presumably because the dominant control on $\mathrm{RH}$ is temperature in these cold biomes. At lower latitudes, the relationship between RH and TAS is weaker, presumably due to other controls on RH such as precipitation and soil moisture. In general, there are strong negative relationships between RH and TAS where soil-moisture and precipitation are limited (cf. Shao et al. 2013).

Few models captured this observed spatial correlation (black line): the CCSM/CESM models (green lines) captured the temporal autocorrelation patterns the best and the MPI and BCC models (cyan and red lines, respectively) performed the worst. Most models

25 tended to perform better in the Northern Hemisphere mid-latitudes, and less well in the Northern Hemisphere sub-tropics where the observed relationship is largely negative. In addition, the model spread of the RH-TAS relationship becomes progressively larger from the Northern Hemisphere to the Southern Hemisphere. This is likely due to less land (and thus higher variability in the model averages) in the Southern Hemisphere, as

30 well as generally fewer RH observations from the Southern Hemisphere more generally (Epule, 2015).

We performed a parallel analysis for RH and PR. The observed $r$ values are strong and positive $(r \geq 0.5, \mathrm{P}<0.005$, Figure $4 \mathrm{~b}$ and Supplementary Figure $2 \mathrm{~b})$, strongest at mid

35 and high latitudes, and weakest in the tropics $\left(20^{\circ} \mathrm{N}\right.$ to $\left.20^{\circ} \mathrm{S}\right)$ along subtropical dry zones. These are also regions where the direction of the relationship is spatially heterogeneous (Supplementary Figure 2b). The modeled relationship between historical RH-PR is stronger than the relationship between RH-TAS, but unlike the RH-TAS relationship, the RH-PR relationship do not exhibit consistent geographical patterns. Interestingly, the 40 models that overestimated the RH-TAS $r$ values (Figure 4a), are the same models that underestimate the RH-PR $r$ values (Figure $4 b$ ).

The observed relationship between RH and NPP is weak (Figure 4c, Supplementary Figure 2c). However, some models have a strong positive relationship (HadGEM

45 models), while others have a strong negative relationship (CCSM4/CESM and NorESM models). The observed strength and direction of the relationship between RH and NPP 
also does not have any spatial heterogeneity.

\subsection{Projected relationships}

5 The projected strength of the local-global RH relationship is shown in Figure 5. The diversity of histogram shapes highlights the ensemble spread, and models from the same modeling center have very similar shapes. The models are grouped into strong (average $\mathrm{R}^{2} \geq 0.75$; bcc, CanESM2, and IPSL models), and weak (average $\mathrm{R}^{2} \leq 0.25$; CCSM4/CESM, MIROC, and NorESM models) $\mathrm{RH}$ local $\left(\mathrm{RH}_{\mathrm{L}}\right)$ and $\mathrm{RH}$ global $\left(\mathrm{RH}_{\mathrm{G}}\right)$ relationships. The GISS-E2 models were separated and emphasized because the localglobal relationship diverged greatly from all other models.

Models with a small $\mathrm{R}^{2}$ between $\mathrm{RH}$ local $\left(\mathrm{RH}_{\mathrm{L}}\right)$ and $\mathrm{RH}$ global $\left(\mathrm{RH}_{\mathrm{G}}\right)$ were generally the most sensitive to changes in $\mathrm{RH}_{\mathrm{G}}$, particularly in the tropics and Southern Hemisphere

15 (Figure 6a), but there was not a clear difference between the strong and weak $\mathrm{R}^{2}$ models. However, the models with a smaller $\mathrm{R}^{2}$ had the smallest $21^{\text {st }}$ century trends (Supplementary Table 1), weak/decreasing year to year standard deviation (Figure 2), and an overestimation of the local-global patterns. Patterns were the least sensitive, i.e. had comparatively small local-global change ratios, at high latitudes and in the tropics. The groupings also emphasize the difference in projected trends for RH and NPP (Figure 6) and those with a small $\mathrm{R}^{2}$ have smaller projected trends than those with a large $\mathrm{R}^{2}$.

The $\mathrm{RH}_{\mathrm{L}}-\mathrm{TAS}_{\mathrm{G}}$ relationship is different from the $\mathrm{RH}_{\mathrm{L}}-\mathrm{RH}_{\mathrm{G}}$ relationship, as there are clearer differences between the stronger and weaker models (Figure 7, 6a-b). For the

25 models with a stronger $\mathrm{RH}_{\mathrm{L}}-\mathrm{TAS}_{\mathrm{G}}$ relationship, $\mathrm{RH}$ is much more sensitive (i.e., the local-global change ratio is larger) to changes in global TAS everywhere (Figure 6b). The relationships and patterns between $\mathrm{RH}_{\mathrm{L}}-\mathrm{PR}_{\mathrm{G}}$ (not shown) are very similar to the $\mathrm{RH}_{\mathrm{L}}-$ $\mathrm{TAS}_{\mathrm{G}}$ relationships. The GISS-E2 models were generally similar to the models with a weak $\mathrm{RH}_{\mathrm{L}}-\mathrm{TAS}_{\mathrm{G}}$ relationship, but, like in Figure 6a, there are clear disparities at the 30 equator and in the Southern Hemisphere (Figure 6b).

The modeled $\mathrm{R}^{2}$ between $\mathrm{NPP}_{\mathrm{L}}-\mathrm{NPP}_{\mathrm{G}}$ stronger and more consistent across models than it is for the $\mathrm{RH}_{\mathrm{L}}-\mathrm{RH}_{\mathrm{G}}$ (Figure 8). For some models (bcc, BNU, CanESM, GISS-E2, and HadGEM models), the $\mathrm{NPP}_{\mathrm{L}}-\mathrm{NPP}_{\mathrm{G}} \mathrm{R}^{2}$ are the inverse of the local-global $\mathrm{R}^{2}$ for $\mathrm{RH}$. The

$35 \mathrm{NPP}_{\mathrm{L}}-\mathrm{NPP}_{\mathrm{G}}$ spatial patterns are similar to the $\mathrm{RH}_{\mathrm{L}}-\mathrm{RH}_{\mathrm{G}}$, but the $\mathrm{NPP}_{\mathrm{L}}-\mathrm{NPP}_{\mathrm{G}}$ sensitivity is stronger around the equator (Figure $6 \mathrm{c}$ ). Models with a weak $\mathrm{RH}_{\mathrm{L}}-\mathrm{RH}_{\mathrm{G}}$ relationship are more sensitive to changes in global NPP. Once again, the GISS-E2 models show very strong local sensitivity to global changes along the equator and in the Southern Hemisphere. The relationships and patterns between local-global NPP are highly similar to $\mathrm{NPP}_{\mathrm{L}}-\mathrm{TAS}_{\mathrm{G}}$ (Figure 9, Figure 6d) and $\mathrm{NPP}_{\mathrm{L}}-\mathrm{PR}_{\mathrm{G}}$ (not shown), but NPP in the GISS-E2 models is highly sensitive to changes in global temperature. 
For the future, the $\mathrm{RH}_{\mathrm{L}}-\mathrm{TAS}_{\mathrm{G}}$ pattern has the best fit as inferred from very low standardized error (Figure 10). This is likely due to the clear and strong global mean temperature signal projected from the RCP 8.5 scenario. The $\mathrm{RH}_{\mathrm{L}}-\mathrm{NPP}_{\mathrm{G}}$ pattern standard error is also low, and similar spatial features of the pattern standard error are evident across all four patterns. Larger errors are evident in the tropics and generally are larger along leeward/eastern coast of most continents.

RMSE values between actual and pattern predicted RH were small, with the lowest RMSE when using the $\mathrm{RH}_{\mathrm{L}}-\mathrm{TAS}_{\mathrm{G}}$ (Table 3). RMSE were smallest for models that had a weak $\mathrm{RH}_{\mathrm{L}}-\mathrm{TAS}_{\mathrm{G}}$ relationship, particularly the CCSM4/CESM, NorESM, and GISS-E2 models. Inversely, RMSE were largest for models with a strong $\mathrm{RH}_{\mathrm{L}}-\mathrm{TAS}_{\mathrm{G}}$ relationship. Low RMSE errors between the actual and predicted RH is likely due to clear and significant global trends (Supplementary Table 1) and the strongly linear local-global relationship between RH and RH/TAS/NPP, which was also shown in Figure 10.

\section{Discussion}

\subsection{Observed trends and relationships, model comparison}

20 In the observed period, both the magnitude and change in global RH are overestimated by the ESMs examined here. Models in the ensemble do not capture the observed trends and magnitudes in RH well, and there is a large model spread in the observed and projected relationship. On one hand, this is unsurprising, as ESMs tend to overestimate the effect strength of $\mathrm{CO}_{2}$ fertilization on other parts of the carbon cycle such as NPP (Smith et al.,

25 2015). On the other, however, the observed RH dataset used in this study may underestimate the real trend due to the simple empirical relationship between soil respiration and RH used to construct the data (Hashimoto et al., 2015). With these caveats in mind, the NorESM and CCSM4/CESM models generally performed best when comparing model performance to observations. These models have identical number of

30 litter and soil pools, temperature and moisture functions, and representation of nitrogen cycling (Todd-Brown et al. 2013, Table 3). In addition, the NorESM and CCSM4/CESM models strongly underestimate total soil carbon, NPP flux, and soil carbon turnover time (Todd-Brown et al. 2013, Figure 2; Hashimoto et al. 2015, Figure 9).

35 Despite a large spread in estimated annual RH, the CMIP5 models robustly project a statistically significant positive trend in global $\mathrm{RH}$ and increased interannual variability under RCP 8.5. The notable exception to the projected increase in interannual variability are the GISS-E2 models, which have no carbon litter pools (Todd-Brown et al., 2013), but a large number (9) of soil pools. Also, temperature and moisture functions of soil

40 carbon estimates in the GISS-E2 models are strongly linear with no upper limit, and there is no nitrogen cycling. For the future period, the GISS-E2 models were also notable in that they project large increases in NPP, but comparatively small trends in RH. The seemingly too-high sensitivity of model RH to changing climate is very tentative, given the limitations on RH observations and available upscaled products (Bond-Lamberty and

45 Thomson, 2010a; Hashimoto et al., 2015; Shao et al., 2013), but if confirmed has significant implications for the assessment of these land models' performance and ability 
Interestingly, model skill in simulating RH does not necessarily correspond to skill in other parts of the carbon cycle. For example, the MIROC and MPI models generally performed the best in simulating $\mathrm{RH}$, but these models largely overestimate soil carbon, NPP, and carbon soil turnover time (Figure 2 in Todd-Brown et al. 2013). The NorESM models in Figure 3 (models 24/25) performed well compared to observations, but in Todd-Brown et al. (Table 3, 2013), the NorESM models had very low Taylor scores across empirical datasets. The reverse is generally true with the HadGEM and IPSL

10 models: Table 3 in Todd-Brown et al. (2013) suggests that the HadGEM2 and IPSL models performed well in capturing observed $\mathrm{RH}$ characteristics, given that they performed well with respect to soil $\mathrm{C}$ turnover time, but these models had large RMSE (error) values in our results (Figure 3 ). These discrepancies could be due a number of reasons: (i) high and divergent spatial variability in certain models, and between models

15 and observations, in the abiotic drivers of RH (ii) an underestimation of global annual RH values in the observed dataset (Hashimoto et al. 2015); and (iii) the fact that models can perform well in reproducing soil $\mathrm{C}$ pools without doing so for fluxes, or vice versa, due to the first-order input and output (i.e., RH) algorithms used (Carvalhais et al., 2010). Robustly constraining and evaluating the ability of ESMs to simulate soil processes will

20 require jointly evaluating their pools as well as fluxes. In this regard, our work extends and complements the results of Todd-Brown et al. (2013).

\subsection{Drivers of RH: observations and models}

25 Because respiration is strongly affected by climate, there is a strong zonal response in observed RH. This is evident in observations, but not in the ESMs. Robust agreement in strength and sign of the RH-TAS relationship is limited to Northern Hemisphere high latitude cold biomes, where TAS is generally considered the dominant control on the soilto-atmosphere $\mathrm{CO}_{2}$ flux (McGuire et al., 2009). As noted in the results, the models that

30 overestimate the RH-TAS relationship are also the models that underestimate the RH-PR relationship, and inversely those that underestimate RH-TAS overestimate RH-PR. In general, there are strong negative relationships between RH and TAS where soil-moisture and precipitation are limited (cf. Shao et al. 2013). This may be a reason why there is such a large spread values/trend in modeled RH.

The observed RH-PR relationship is strong, but the models strongly underestimate the observed RH-PR relationship. The observed zonal features of the RH-PR relationship are also not captured by the models. Given that the models do poorly in capturing the observed relationship, it is not surprising that Table 4 from Todd-Brown et al. 2013,

40 indicates that by including a soil moisture term, the models do not perform better in capturing NPP (instead, they found that modeled NPP is largely constrained by TAS). Some of this discrepancy may be due to the complicated scaling dynamics that occur in carbon-cycle drivers (Jung et al., 2017). Another reason for this inconsistency may in part be due to robust overestimation in seasonal and annual precipitation by the CMIP5

45 models (Liu et al., 2014). In semi-arid regions, high inter-model precipitation variability is also a problem. 
The observed relationship between RH and NPP is not strong. While at the global scale the NPP (Zhao and Running, 2010) and RH (Hashimoto et al., 2015) carbon fluxes are of similar magnitude, and in theory should be equal in steady-state ecosystems (Chapin et al., 2006), this was not true in either the models or observations examined here (Figure 6). There are many possible reasons for this: lag effects between climate-driven NPP changes and RH equilibrium (Baldocchi et al., 2006; Zhou et al., 2010); lag effects from past disturbances (Harmon et al., 2011); and poorly measured storage terms. The weak observed RH-NPP relationship may also be partially due to the short time span used

10 (2000-2013) in calculating the observed relationship, which both increases error and is short relative to SOC turnover times (Todd-Brown et al., 2013). Another potential problem with the observed datasets used may be that we are comparing a bottom-up statistical product (RH) with a top-down satellite/model one (NPP), with inevitable spatial and methodological mismatches. Moreover, studies disagree in strength and

15 direction of observed NPP trends. From satellite based data the trend is slightly negative (Zhao and Running, 2010), but from modeled studies which assimilate observed data (Ahlström et al., 2012; Sitch et al., 2015), the trend is strongly positive.

The modeled RH-NPP relationship is much stronger than the observed relationship. The notable exception to this is the CCSM4/CESM models (green lines in Figures 4, 5, and 6) which have a negative RH-NPP relationship in the tropics and in the Southern Hemisphere. However, the model spread is quite large, with no notable zonal features. This may indicate that the models are too closely coupled, i.e. that their production and decomposition functions are too tightly tied to each other (Hashimoto et al., 2015), or

25 perhaps that the modeled parameterizations in RH/NPP quantification are too simple to capture necessary feedbacks in the carbon cycle. Theoretically at least, an RH-NPP relationship is expected at some scale, so it is difficult to diagnose whether the issue is with the observations used or model parameterizations that couple the RH-NPP flux. Furthermore, most models overestimate observed NPP trends and values (Todd-Brown et al. 2013), which may contribute to stronger than observed RH-NPP $r$ values.

Overall, modeled RH sensitivity to climatic factors seems unlikely to be correct (Zhou et al. 2009; Shao et al. 2013; (Shao et al., 2013; Sierra et al., 2015; Smith et al., 2015)). At high Northern latitudes, the models underestimate both the temperature and precipitation (as a proxy for soil moisture) relationships compared to the Hashimoto et al. (2015) observationally-based dataset. This may be because it has been shown that carbon system model decomposition rates have a low sensitivity to climate factors in cold regions with limited moisture (Sierra et al., 2015). The soil respiration temperature response $\left(\mathrm{Q}_{10}\right)$ range in Earth system models is large, but is generally stronger than that

40 derived from observational studies (Beer et al., 2010; Bond-Lamberty and Thomson, 2010b; 2015), and ESMs in general exhibit strong carbon cycle responses to climate change (Anav et al., 2013, 2015; Ito et al., 2017). This likely contributes to the large model spread in $\mathrm{RH}$. The common practice of using a global constant $\mathrm{Q}_{10}$ term rather than a spatially heterogeneous $\mathrm{Q}_{10}$ may also contribute to this over/underestimation (Zhou et al., 2009). 


\subsection{Evaluation and discussion of projected $R H$ and pattern scaling}

Despite large differences in local-global $\mathrm{RH} \mathrm{R}^{2}$ values, the local sensitivity to global change ("patterns") is small and largely consistent across models. Given the large ensemble spread in projected global $\mathrm{RH}$, it is interesting that the $\mathrm{RH}-\mathrm{RH}$ patterns are so similar, with the largest differences at the equator. Models with large $\mathrm{RH}_{\mathrm{L}}-\mathrm{RH}_{\mathrm{G}} \mathrm{R}^{2}$ values are also more sensitive to global TAS change. TAS (and NPP) is better parameterized in the ESM models than RH, and as such is likely to yield a more robust response in local RH with stronger confidence in the resulting pattern. Todd-Brown et al.

10 (2013 and 2014) found that NPP and soil carbon are strongly tied to temperature. This relationship is also evident in the observed data (Hashimoto et al. 2015) and has great potential for use in pattern scaling studies to examine alternative forcing scenarios.

As shown in Table 3, the $\mathrm{RH}_{\mathrm{L}}-\mathrm{TAS}_{\mathrm{G}}$, and to a lesser extent, the $\mathrm{RH}_{\mathrm{L}}-\mathrm{NPP}_{\mathrm{G}}$, relationship can be used to reproduce spatial RH features with comparatively low RMSE values. This raises the possibility that pattern scaling techniques, which are straightforward to implement and computationally inexpensive, could be used as a routine diagnostic for ESM outputs. In particular, these techniques may be valuable with respect to RH, a flux for which so few observational data exist and the model-measurement spatial mismatch is extremely large (Bond-Lamberty et al., 2016; Zhou et al., 2009).

Model comparisons in the earth sciences need to be performed carefully with a full understanding of their limitations (Oreskes et al., 1994). Nonetheless, it is important to note that in this analysis the GISS-E2 models (Schmidt et al., 2014) are significant

25 outliers in both their projected local-global RH relationships and temperature sensitivity. Todd-Brown et al (2013) noted that these models exhibited a noticeable discrepancy between NPP and soil carbon, which was partially attributed to the allocation of plant biomass in the litter model. The GISS-E2 models also are characterized by very low equilibrium climate sensitivity, transient climate response, and GHG-attributable

30 warming (Gillett et al., 2013), and projected changes in terrestrial carbon and surface temperature are not likely to be strongly coupled.

Finally, it is important to note that like any analytical technique, pattern scaling has both strengths and weaknesses. Patterns can be used to examine model differences in response to particular forcings or trends in global climate parameters, diagnose problem relationships, explore future emission sensitivity, and show where relationships are weak or non-linear. However, pattern scaling, as a statistical emulation method, is strongly tied to the assumption of stationarity (Mitchell, 2003). Patterns derived from emission scenarios with strong mitigation are less accurate and prone to large estimation errors

40 (Tebaldi and Arblaster, 2014). Finally, if the projected trend in RH and/or the predictor variable is weak, the pattern error term is relatively large, and pattern scaling should be used with caution.

\section{Acknowledgements}

This research is based on work supported by the US Department of Energy, Office of 
Biogeosciences Discuss., https://doi.org/10.5194/bg-2017-405

Manuscript under review for journal Biogeosciences

Discussion started: 12 October 2017

(c) Author(s) 2017. CC BY 4.0 License.

Science, Integrated Assessment Research Program. The Pacific Northwest National Laboratory is operated for DOE by Battelle Memorial Institute under contract DE-AC0576RL01830.

\section{$5 \quad$ Code and data availability}

Code used to complete this analysis was done primarily in NCL and will be available in a GitHub repository once the paper is accepted. All data used in this analysis are given in Tables 1 and 2 and are openly available to the public.

\section{References}

Adler, R. F., Huffman, G. J., Chang, A., Ferraro, R., Xie, P.-P., Janowiak, J., Rudolf, B., Schneider, U., Curtis, S., Bolvin, D., Gruber, A., Susskind, J., Arkin, P. and Nelkin, E.: The Version-2 Global Precipitation Climatology Project (GPCP) Monthly Precipitation Analysis (1979-Present), J. Hydrometeorol., 4(6), 1147-1167, 2003.

Ahlström, A., Schurgers, G., Arneth, A. and Smith, B.: Robustness and uncertainty in terrestrial ecosystem carbon response to CMIP5 climate change projections, Environ. Res. Lett., 7(4), 044008, 2012.

Anav, A., Friedlingstein, P., Kidston, M., Bopp, L., Ciais, P., Cox, P. M., Jones, C. D., Jung, M.,

20 Myneni, R. B. and Zhu, Z.: Evaluating the land and ocean components of the global carbon cycle in the CMIP5 earth system models, J. Clim., 26, 6801-6843, 2013.

Anav, A., Friedlingstein, P., Beer, C., Ciais, P., Harper, A., Jones, C., Murray-Tortarolo, G., Papale, D., Parazoo, N. C., Peylin, P., Piao, S., Sitch, S., Viovy, N., Wiltshire, A. and Zhao, M.: Spatiotemporal patterns of terrestrial gross primary production: A review, Rev. Geophys., 53(3), 2015RG000483, 2015.

Baldocchi, D. D., Tang, J. and Xu, L.: How switches and lags in biophysical regulators affect spatial-temporal variation of soil respiration in an oak-grass savanna, Journal of Geophysical Research-Biogeosciences, 111, G02008, 2006.

Beer, C., Reichstein, M., Tomelleri, E., Ciais, P., Jung, M., Carvalhais, N., Rödenbeck, C., Arain, 30 M. A., Baldocchi, D. D., Bonan, G. B., Bondeau, A., Cescatti, A., Lasslop, G., Lindroth, A., Lomas, M. R., Luyssaert, S., Margolis, H. A., Oleson, K. W., Roupsard, O., Veenendaal, E., Viovy, N., Williams, C. A., Woodward, F. I. and Papale, D.: Terrestrial gross carbon dioxide uptake: global distribution and covariation with climate, Science, 329(5993), 834-838, 2010.

Bond-Lamberty, B. and Thomson, A. M.: A global database of soil respiration data,

Bond-Lamberty, B. and Thomson, A. M.: Temperature-associated increases in the global soil respiration record, Nature, 464(7288), 579-582, 2010b.

Bond-Lamberty, B., Wang, C. and Gower, S. T.: A global relationship between the heterotrophic and autotrophic components of soil respiration, Glob. Chang. Biol., 10(10), 1756-1766, 2004.

40 Bond-Lamberty, B., Epron, D., Harden, J. W., Harmon, M. E., Hoffman, F. M., Kumar, J., McGuire, A. D. and Vargas, R.: Estimating heterotrophic respiration at large scales: challenges, 
Biogeosciences Discuss., https://doi.org/10.5194/bg-2017-405

Manuscript under review for journal Biogeosciences

Discussion started: 12 October 2017

(c) Author(s) 2017. CC BY 4.0 License.

approaches, and next steps, Ecosphere, 7(6), d01380, 2016.

Carvalhais, N., Reichstein, M., Ciais, P., Collatz, G. J., Mahecha, M. D., Montagnani, L., Papale, D., Rambal, S. and Seixas, J.: Identification of vegetation and soil carbon pools out of equilibrium in a process model via eddy covariance and biometric constraints, Glob. Chang. Biol., 16(10), 2813-2829, 2010.

Chapin, F. S., Woodwell, G. M., Randerson, J. T., Rastetter, E. B., Lovett, G. M., Baldocchi, D. D., Clark, D. A., Harmon, M. E., Schimel, D. S., Valentini, R., Wirth, C., Aber, J. D., Cole, J. J., Goulden, M. L., Harden, J. W., Heimann, M., Howarth, R. W., Matson, P. A., McGuire, A. D., Melillo, J. M., Mooney, H. A., Neff, J. C., Houghton, R. A., Pace, M. L., Ryan, M. G., Running,

10 S. W., Sala, O. E., Schlesinger, W. H. and Schulze, E.-D.: Reconciling carbon-cycle concepts, terminology, and methods, Ecosystems, 9(7), 1041-1050, 2006.

Epule, T. E.: A new compendium of soil respiration data for Africa, Challenges, 6(1), 88-97, 2015.

Friedlingstein, P., Meinshausen, M., Arora, V., Jones, C. D., Anav, A., Liddicoat, S. and Knutti,

15 R.: Uncertainties in CMIP5 climate projections due to carbon cycle feedbacks, J. Clim., 27, 511$526,2014$.

Gillett, N. P., Arora, V. K., Matthews, D. and Allen, M. R.: Constraining the Ratio of Global Warming to Cumulative CO2 Emissions Using CMIP5 Simulations, J. Clim., 26(18), 6844-6858, 2013.

20 Harmon, M. E., Bond-Lamberty, B., Vargas, R. and Tang, J.: Heterotrophic respiration in disturbed forests: a review with examples from North America, Journal of Geophysical ResearchBiogeosciences, 116, G00K04, 2011.

Hashimoto, S.: A new estimation of global soil greenhouse gas fluxes using a simple dataoriented model, PLoS One, 7(8), e41962, 2012.

25 Hashimoto, S., Carvalhais, N., Ito, A., Migliavacca, M., Nishina, K. and Reichstein, M.: Global spatiotemporal distribution of soil respiration modeled using a global database, Biogeosciences, $12,4121-4132,2015$.

Hursh, A., Ballantyne, A. P., Cooper, L., Maneta, M., Kimball, J. S. and Watts, J.: The sensitivity of soil respiration to soil temperature, moisture, and carbon supply at the global scale, Glob.

30 Chang. Biol., in press, doi:10.1111/gcb.13489, 2016.

Ito, A., Nishina, K., Reyer, C. P. O., François, L., Henrot, A.-J., Munhoven, G., Jacquemin, I., Tian, H., Yang, J., Pan, S., Morfopoulos, C., Betts, R., Hickler, T., Steinkamp, J., Ostberg, S., Schaphoff, S., Ciais, P., Chang, J., Rafique, R., Zeng, N. and Zhao, F.: Photosynthetic productivity and its efficiencies in ISIMIP2a biome models: benchmarking for impact assessment studies, Environ. Res. Lett., 12(8), 085001, 2017.

Jung, M., Reichstein, M., Schwalm, C. R., Huntingford, C., Sitch, S., Ahlström, A., Arneth, A., Camps-Valls, G., Ciais, P., Friedlingstein, P., Gans, F., Ichii, K., Jain, A. K., Kato, E., Papale, D., Poulter, B., Raduly, B., Rödenbeck, C., Tramontana, G., Viovy, N., Wang, Y.-P., Weber, U., Zaehle, S. and Zeng, N.: Compensatory water effects link yearly global land CO2 sink changes to temperature, Nature, 541(7638), 516-520, 2017. 
Biogeosciences Discuss., https://doi.org/10.5194/bg-2017-405

Manuscript under review for journal Biogeosciences

Discussion started: 12 October 2017

(c) Author(s) 2017. CC BY 4.0 License.

Kalnay, E., Kanamitsu, M., Kistler, R., Collins, W. D., Deaven, D., Gandin, L., Iredell, M., Saha, S., White, G., Woollen, J., Zhu, Y., Chelliah, M., Ebisuzaki, W., Higgins, W., Janowiak, K., Mo, C., Ropelewski, C., Wang, J., Leetmaa, A., Reynolds, R., Jenne, R. and Joseph, D.: The NCEP/NCAR 40-year reanalysis project, Bull. Am. Meteorol. Soc., 77, 437-471, 1996.

5 Kravitz, B., Lynch, C., Hartin, C. and Bond-Lamberty, B.: Exploring precipitation pattern scaling methodologies and robustness among CMIP5 models, Geoscientific Model Development, 10(5), 1889-1902, 2017.

Li, G., Kim, S., Han, S. H., Chang, H. and Son, Y.: Effect of Soil Moisture on the Response of Soil Respiration to Open-Field Experimental Warming and Precipitation Manipulation, For. Trees Livelihoods, 8(3), 56, 2017.

Liu, L., Wang, X., Lajeunesse, M. J., Miao, G., Piao, S., Wan, S., Wu, Y., Wang, Z., Yang, S. and Deng, M.: A cross-biome synthesis of soil respiration and its determinants under simulated precipitation changes, Glob. Chang. Biol., 22(4), 1394-1405, 2016.

Liu, Z., Mehran, A., Phillips, T. J. and AghaKouchak, A.: Seasonal and regional biases in CMIP5 precipitation simulations, Clim. Res., 60(1), 35-50, 2014.

Luo, Y. and Zhou, X.: Soil Respiration and the Environment, Elsevier/Academic Press, Amsterdam., 2006.

Lynch, C., Hartin, C., Bond-Lamberty, B. and Kravitz, B.: An open-access CMIP5 pattern library for temperature and precipitation: description and methodology, Earth System Science Data, 9(1), 281-292, 2017.

McGuire, A. D., Anderson, L. G., Christensen, T. R., Dallimore, S., Guo, L., Hayes, D. J., Heimann, M., Lorenson, T. D., Macdonald, R. W. and Roulet, N. T.: Sensitivity of the carbon cycle in the Arctic to climate change, Ecol. Monogr., 79(4), 523-555, 2009.

Mitchell, T. D.: Pattern Scaling: An Examination of the Accuracy of the Technique for

25 Describing Future Climates, Clim. Change, 60(3), 217-242, 2003.

Oreskes, N., Shrader-Frechette, K. and Belitz, K.: Verification, validation, and confirmation of numerical models in the earth sciences, Science, 263(5147), 641-646, 1994.

Osborn, T. J.: A user guide for ClimGen: a flexible tool for generating monthly climate data sets and scenarios, Climatic Research Unit, University of East Anglia, Norwich, 17, 2009.

30 Riahi, K., Rao, S., Krey, V., Cho, C., Chirkov, V., Fischer, G., Kindermann, G., Nakicenovic, N. and Rafaj, P.: RCP 8.5-A scenario of comparatively high greenhouse gas emissions, Clim. Change, 109(1-2), 33, 2011.

Santer, B. D., Wigley, T., Schlesinger, M. E. and Mitchell, J. F. B.: Developing Climate Scenarios from Equilibrium GCM Results, Max-Planck-Institut für Meteorologie, Hamburg., 1990.

Schmidt, G. A., Kelley, M., Nazarenko, L., Ruedy, R., Russell, G. L., Aleinov, I., Bauer, M., Bauer, S. E., Bhat, M. K., Bleck, R., Canuto, V., Chen, Y.-H., Cheng, Y., Clune, T. L., Del Genio, A., de Fainchtein, R., Faluvegi, G., Hansen, J. E., Healy, R. J., Kiang, N. Y., Koch, D., Lacis, A. A., LeGrande, A. N., Lerner, J., Lo, K. K., Matthews, E. E., Menon, S., Miller, R. L., 
Biogeosciences Discuss., https://doi.org/10.5194/bg-2017-405

Manuscript under review for journal Biogeosciences

Discussion started: 12 October 2017

(c) Author(s) 2017. CC BY 4.0 License.

Oinas, V., Oloso, A. O., Perlwitz, J. P., Puma, M. J., Putman, W. M., Rind, D., Romanou, A., Sato, M., Shindell, D. T., Sun, S., Syed, R. A., Tausnev, N., Tsigaridis, K., Unger, N., Voulgarakis, A., Yao, M.-S. and Zhang, J.: Configuration and assessment of the GISS ModelE2 contributions to the CMIP5 archive, J. Adv. Model. Earth Syst., 6(1), 141-184, 2014.

5 Shao, P., Zeng, X., Moore, D. J. P. and Zeng, X.: Soil microbial respiration from observations and Earth System Models, Environ. Res. Lett., 8(3), 034034, 2013.

Sierra, C. A., Trumbore, S. E., Davidson, E. A., Vicca, S. and Janssens, I. A.: Sensitivity of decomposition rates of soil organic matter with respect to simultaneous changes in temperature and moisture, Journal of Advances in Modeling Earth Systems, 7(1), 335-356, 2015.

10 Sitch, S., Friedlingstein, P., Gruber, N., Jones, S. D., Murray-Tortarolo, G., Ahlström, A., Doney, S. C., Graven, H. D., Heinze, C., Huntginford, C., Levis, S., Levy, P., Lomas, M. R., Poulter, B., Viovy, N., Zaehle, S., Zeng, N., Arneth, A., Bonan, G. B., Bopp, L., Canadell, J. G., Chevallier, F., Ciais, P., Ellis, R. C., Gloor, E., Peylin, P., Piao, S., Le Quéré, C., Smith, B., Zhu, Z. and Myneni, R. B.: Recent trends and drivers of regional sources and sinks of carbon dioxide, Biogeosciences, 12, 653-679, 2015.

Smith, W. K., Reed, S. C., Cleveland, C. C., Ballantyne, A. P., Anderegg, W. R. L., Wieder, W. R., Liu, Y. Y. and Running, S. W.: Large divergence of satellite and Earth system model estimates of global terrestrial $\mathrm{CO} 2$ fertilization, Nat. Clim. Chang., in press, doi:10.1038/nclimate2879, 2015.

20 Taylor, K. E., Stouffer, R. J. and Meehl, G. A.: An overview of CMIP5 and the experiment design, Bull. Am. Meteorol. Soc., 93, 485-498, 2012.

Tebaldi, C. and Arblaster, J. M.: Pattern scaling: Its strengths and limitations, and an update on the latest model simulations, Clim. Change, 122(3), 459-471, 2014.

Todd-Brown, K. E. O., Randerson, J. T., Post, W. M., Hoffman, F. M., Tarnocai, C., Schuur, E.

25 A. G. and Allison, S. D.: Causes of variation in soil carbon predictions from CMIP5 Earth system models and comparison with observations, Biogeosciences, 10, 1717-1736, 2013.

Todd-Brown, K. E. O., Randerson, J. T., Hopkins, F., Arora, V., Hajima, T., Jones, C., Shevliakova, E., Tjiputra, J., Volodin, E., Wu, T., Zhang, Q., and Allison, S. D.: Changes in soil organic carbon storage predicted by Earth system models during the 21st century,

30 Biogeosciences, 11, 2341-2356, 2014.

Wieder, W. R., Bonan, G. B. and Allison, S. D.: Global soil carbon projections are improved by modelling microbial processes, Nat. Clim. Chang., 3, 909-912, 2013.

Zhao, M. and Running, S. W.: Drought-induced reduction in global terrestrial net primary

35 production from 2000 through 2009, Science, 329(5994), 940-943, 2010.

Zhao, M., Heinsch, F. A., Nemani, R. R. and Running, S. W.: Improvements of the MODIS terrestrial gross and net primary production global data set, Remote Sens. Environ., 95(2), 164 176,2005 .

Zhou, T., Phi, P., Hui, D. and Luo, Y.: Global pattern of temperature sensitivity of soil 40 heterotrophic respiration $(\mathrm{Q}(10))$ and its implications for carbon-climate feedback, Journal of Geophysical Research-Biogeosciences, 114, G02016, 2009. 
Biogeosciences Discuss., https://doi.org/10.5194/bg-2017-405

Manuscript under review for journal Biogeosciences

Discussion started: 12 October 2017

(c) Author(s) 2017. CC BY 4.0 License.

Zhou, X., Luo, Y., Gao, C., Verburg, P. S. J., Arnone, J. A., III, Darrouzet-Nardi, A. and Schimel, D. S.: Concurrent and lagged impacts of an anomalously warm year on autotrophic and heterotrophic components of soil respiration: a deconvolution analysis, New Phytol., 187(1), 184-198, 2010.

5 Todd-Brown, K. E. O., Randerson, J. T., Hopkins, F., Arora, V., Hajima, T., Jones, C., Shevliakova, E., TJiputra, J., Volodin, E., Wu, T., Zhang, Q., and Allison, S. D.: Changes in soil organic carbon storage predicted by Earth system models during the 21 st century, Biogeosciences, 11, 2341-2356, 2014.

Xu, M., and Shang, H.: Contribution of soil respiration to the global carbon equation, Journal of Plant Physiology, 203, 16-28, 2016. 


\section{Tables and Figures}

Table 1. List of datasets and their attributes used in this analysis.

\begin{tabular}{|c|c|c|c|}
\hline Variable & $\begin{array}{c}\text { Spatial } \\
\text { Resolution }\end{array}$ & $\begin{array}{l}\text { Temporal } \\
\text { Resolution }\end{array}$ & Source (version) \\
\hline $\begin{array}{l}\text { Heterotrophic } \\
\text { Respiration (RH) }\end{array}$ & $0.5^{\circ} \times 0.5^{\circ}$ & $\begin{array}{c}\text { Annual, 1901- } \\
2013\end{array}$ & $\begin{array}{l}\text { Soil Respiration Database } \\
\text { (SRDB), Department of Energy } \\
\text { (DOE) Pacific Northwest } \\
\text { National Laboratory (PNNL) }\end{array}$ \\
\hline $\begin{array}{l}\text { Surface Air } \\
\text { Temperature (TAS) }\end{array}$ & $2.5^{\circ} \times 2.5^{\circ}$ & $\begin{array}{l}\text { Monthly, } \\
\text { 1948-2013 }\end{array}$ & $\begin{array}{l}\text { National Centers for } \\
\text { Environmental Prediction, } \\
\text { National Center for Atmospheric } \\
\text { Research (NCEP/NCAR) } \\
\text { Reanalysis Project 1, National } \\
\text { Oceanic and Atmospheric } \\
\text { Administration (NOAA), Earth } \\
\text { System Research Laboratory } \\
\text { Physical Sciences Division }\end{array}$ \\
\hline $\begin{array}{l}\text { Precipitation Flux } \\
\text { (PR) }\end{array}$ & $2.5^{\circ} \times 2.5^{\circ}$ & $\begin{array}{l}\text { Monthly, } \\
\text { 1979-2013 }\end{array}$ & $\begin{array}{l}\text { Global Precipitation } \\
\text { Climatology Project, National } \\
\text { Aeronautics and Space } \\
\text { Administration (NASA) } \\
\text { Goddard Space Flight Center }\end{array}$ \\
\hline $\begin{array}{l}\text { Net Primary } \\
\text { Production (NPP) }\end{array}$ & $0.5^{\circ} \times 0.5^{\circ}$ & $\begin{array}{c}\text { Annual, 2000- } \\
2013\end{array}$ & $\begin{array}{l}\text { NASA MODIS TERRA product } \\
\text { ID: MOD17A3 }\end{array}$ \\
\hline
\end{tabular}

Table 2. List of the CMIP5 models used in this analysis, with their respective spatial resolution and organization.

\begin{tabular}{|l|l|l|}
\hline Model & $\begin{array}{l}\text { Spatial } \\
\text { Resolution }\end{array}$ & Organization \\
\hline bcc-csm1-1 & $2.8^{\circ} \times 2.8^{\circ}$ & $\begin{array}{l}\text { Beijing Climate Center, China Meteorological } \\
\text { Administration, China }\end{array}$ \\
\hline bcc-csm1-1-m & $1^{\circ} \times 1^{\circ}$ & \\
\hline BNU-ESM & $2.8^{\circ} \times 2.8^{\circ}$ & $\begin{array}{l}\text { College of Global Change and Earth System } \\
\text { Science, Beijing Normal University, China }\end{array}$ \\
\hline CanESM2 & $2.8^{\circ} \times 2.8^{\circ}$ & Canadian Centre for Climate Modeling and \\
\hline
\end{tabular}




\begin{tabular}{|c|c|c|}
\hline & & Analysis, Canada \\
\hline CCSM4 & $1^{\circ} \times 1.25^{\circ}$ & $\begin{array}{l}\text { NCAR, University Corporation for Atmospheric } \\
\text { Research, U.S.A. }\end{array}$ \\
\hline CESM1-BGC & \multirow[t]{2}{*}{$1^{\circ} \times 1.25^{\circ}$} & \multirow[t]{3}{*}{$\begin{array}{l}\text { National Science Foundation/DOE, NCAR, } \\
\text { U.S.A. }\end{array}$} \\
\hline CESM1-CAM5 & & \\
\hline CESM1-WACCM & $1.8^{\circ} \times 2.5^{\circ}$ & \\
\hline GFDL-ESM2G & \multirow[t]{2}{*}{$2^{\circ} \times 2.5^{\circ}$} & \multirow[t]{2}{*}{$\begin{array}{l}\text { NOAA, Geophysical Fluid Dynamic } \\
\text { Laboratory, U.S.A. }\end{array}$} \\
\hline GFDL-ESM2M & & \\
\hline GISS-E2-H & \multirow[t]{4}{*}{$2^{\circ} \times 2.5^{\circ}$} & \multirow[t]{4}{*}{$\begin{array}{l}\text { NASA, Goddard Institute for Space Studies, } \\
\text { U.S.A. }\end{array}$} \\
\hline GISS-E2-H-CC & & \\
\hline GISS-E2-R & & \\
\hline GISS-E2-R-CC & & \\
\hline HadGEM2-CC & \multirow[t]{2}{*}{$1.2^{\circ} \times 1.8^{\circ}$} & \multirow[t]{2}{*}{ Meteorological Office Hadley Centre, U.K. } \\
\hline HadGEM2-ES & & \\
\hline IPSL-CM5A-LR & $1.8^{\circ} \times 3.75^{\circ}$ & \multirow[t]{3}{*}{$\begin{array}{l}\text { Laboratoire de Meteorologique Dynamique, } \\
\text { Institut Pierre-Simon Laplace, France }\end{array}$} \\
\hline IPSL-CM5A-MR & $1.25^{\circ} \times 2.5^{\circ}$ & \\
\hline IPSL-CM5B-LR & $1.8^{\circ} \times 3.75^{\circ}$ & \\
\hline MIROC-ESM & \multirow[t]{2}{*}{$2.8^{\circ} \times 2.8^{\circ}$} & \multirow{2}{*}{$\begin{array}{l}\text { Atmosphere and Ocean Research Institute, } \\
\text { National Institute for Environmental Studies, } \\
\text { and Japan Agency for Marine-Earth Science and } \\
\text { Technology, Japan }\end{array}$} \\
\hline $\begin{array}{l}\text { MIROC-ESM- } \\
\text { CHEM }\end{array}$ & & \\
\hline MPI-ESM-LR & $1.8^{\circ} \times 1.8^{\circ}$ & Max Planck Institute for Meteorology, Germany \\
\hline
\end{tabular}




\begin{tabular}{|l|l|l|}
\hline MPI-ESM-MR & & \\
\cline { 1 - 1 } NorESM1-M & \multirow{2}{*}{$1.8^{\circ} \times 1.8^{\circ}$} & Norwegian Climate Centre, Norway \\
\cline { 1 - 1 } NorESM1-ME & & \\
\hline
\end{tabular}

Table 3: Root mean square error between modeled heterotrophic respiration (RH) and pattern predicted $\mathrm{RH}$ at the end of the $21^{\text {st }}$ century (averaged over 2070-2099) from the RCP 8.5 scenario in $\mathrm{Pg} \mathrm{C} \mathrm{yr}^{-1}$. The patterns used are the $\mathrm{RH}_{\mathrm{L}}$ to $\mathrm{RH}_{\mathrm{G}} / \mathrm{TAS}_{\mathrm{G}} / \mathrm{NPP}_{\mathrm{G}}$.

\begin{tabular}{|l|c|c|c|}
\hline Model & $\mathbf{R H}_{\mathbf{L}}-\mathbf{R H}_{\mathbf{G}}$ & $\mathbf{R H}_{\mathbf{L}} \mathbf{- \mathbf { T A S } _ { \mathbf { G } }}$ & $\mathbf{R H}_{\mathbf{L}}-\mathbf{N P P}_{\mathbf{G}}$ \\
\hline bcc-csm1-1 & 0.278 & 0.255 & 0.219 \\
\hline bcc-csm1-1-m & 0.319 & 0.260 & 0.259 \\
\hline BNU-ESM & 0.338 & 0.319 & 0.430 \\
\hline CanESM2 & 0.179 & 0.114 & 0.370 \\
\hline CCSM4 & 0.192 & 0.106 & 0.122 \\
\hline CESM1-BGC & 0.188 & 0.112 & 0.129 \\
\hline CESM1-CAM5 & 0.228 & 0.097 & 0.160 \\
\hline CESM1-WACCM & 0.235 & 0.093 & 0.166 \\
\hline GFDL-ESM2G & 0.301 & 0.239 & 0.195 \\
\hline GFDL-ESM2M & 0.430 & 0.209 & 0.593 \\
\hline GISS-E2-H & 0.280 & 0.157 & 0.144 \\
\hline GISS-E2-H-CC & 0.265 & 0.159 & 0.189 \\
\hline GISS-E2-R & 0.135 & 0.127 & 0.091 \\
\hline GISS-E2-R-CC & 0.138 & 0.144 & 0.087 \\
\hline HadGEM2-CC & 0.607 & 0.907 & 0.489 \\
\hline HadGEM2-ES & 0.649 & 0.808 & 0.683 \\
\hline IPSL-CM5A-LR & 0.555 & 0.418 & 0.493 \\
\hline
\end{tabular}


Biogeosciences Discuss., https://doi.org/10.5194/bg-2017-405

Manuscript under review for journal Biogeosciences

Discussion started: 12 October 2017

(c) Author(s) 2017. CC BY 4.0 License.

\begin{tabular}{|l|c|c|c|}
\hline IPSL-CM5A-MR & 0.457 & 0.326 & 0.435 \\
\hline IPSL-CM5B-LR & 0.239 & 0.369 & 0.186 \\
\hline MIROC-ESM & 0.624 & 0.650 & 0.511 \\
\hline $\begin{array}{l}\text { MIROC-ESM- } \\
\text { CHEM }\end{array}$ & 0.708 & 0.666 & 1.012 \\
\hline MPI-ESM-LR & 0.240 & 0.375 & 0.178 \\
\hline MPI-ESM-MR & 0.377 & 0.234 & 0.421 \\
\hline NorESM1-M & 0.130 & 0.090 & 0.083 \\
\hline NorESM1-ME & 0.226 & 0.113 & 0.208 \\
\hline Ensemble Average & 0.220 & 0.188 & 0.236 \\
\hline
\end{tabular}

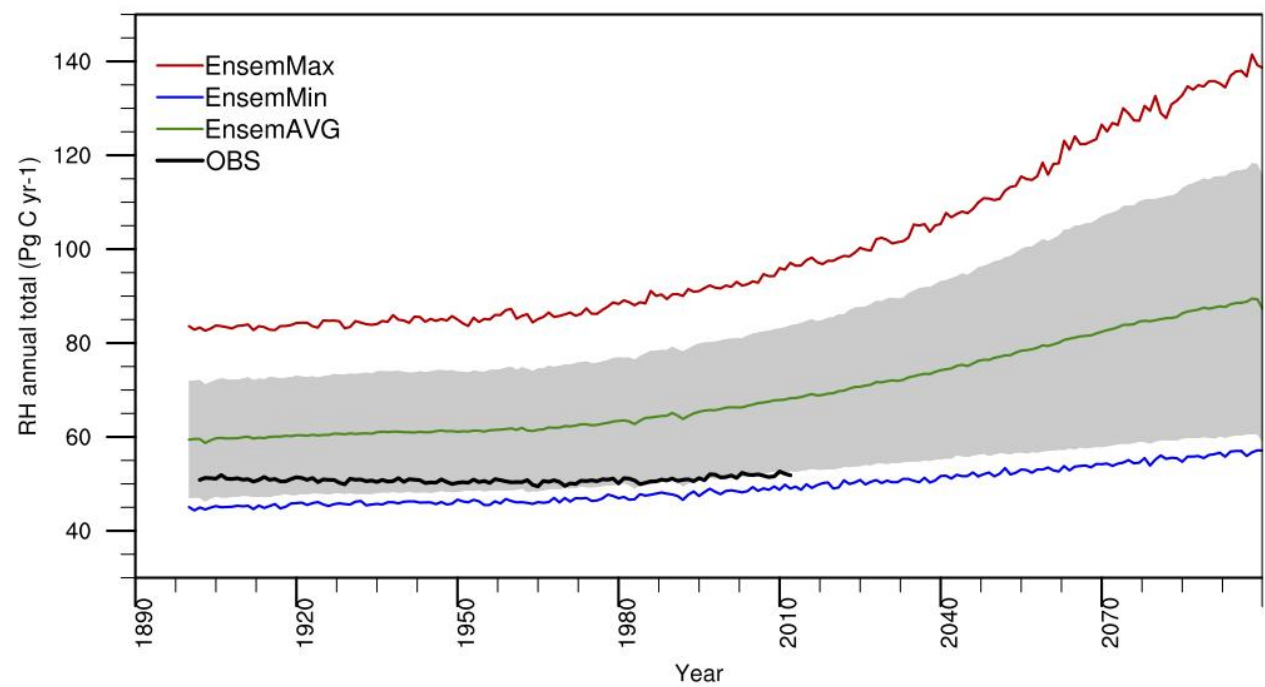

5 Figure 1: Annual global heterotrophic respiration (RH) for 25 CMIP5 models, combining the RCP 8.5 and historical outputs. The green line is the ensemble mean; grey shading is $\pm 1 \sigma$ of multi-model ensemble mean; red and blue lines show the ensemble maximum and minimum values, respectively. Black line is the 'observed' global annual RH from 1901-2100 from Hashimoto et al. (2015). 
Biogeosciences Discuss., https://doi.org/10.5194/bg-2017-405

Manuscript under review for journal Biogeosciences

Discussion started: 12 October 2017

(c) Author(s) 2017. CC BY 4.0 License.

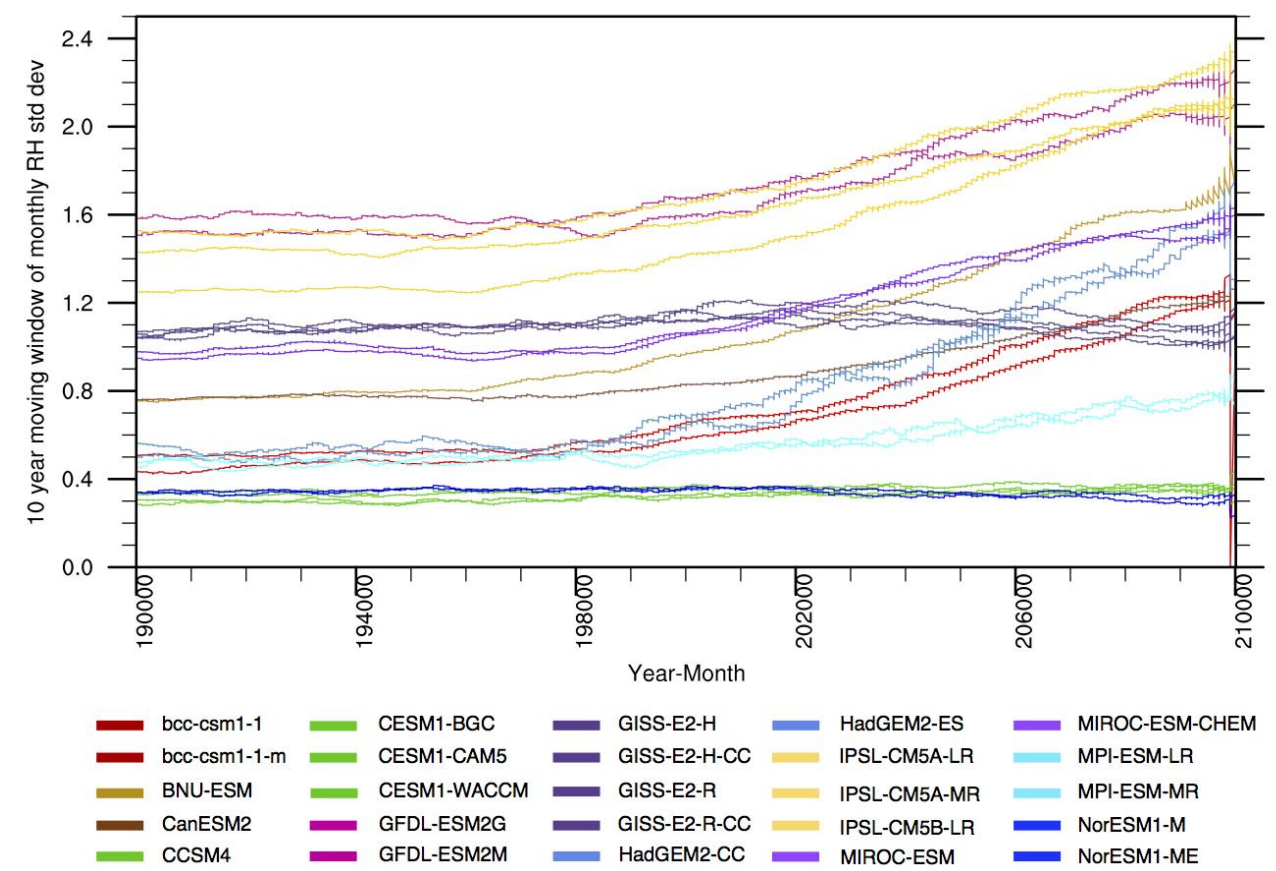

Figure 2: Global heterotrophic respiration $(\mathrm{RH})$ inter-annual standard deviation from each model in months since January 1900. A 10-year (120 month) moving window was applied to monthly values from 1900 to 2100 from historical and RCP 8.5 scenarios. Line colors correspond to models from same modeling center. 
Biogeosciences Discuss., https://doi.org/10.5194/bg-2017-405

Manuscript under review for journal Biogeosciences

Discussion started: 12 October 2017

(c) Author(s) 2017. CC BY 4.0 License.

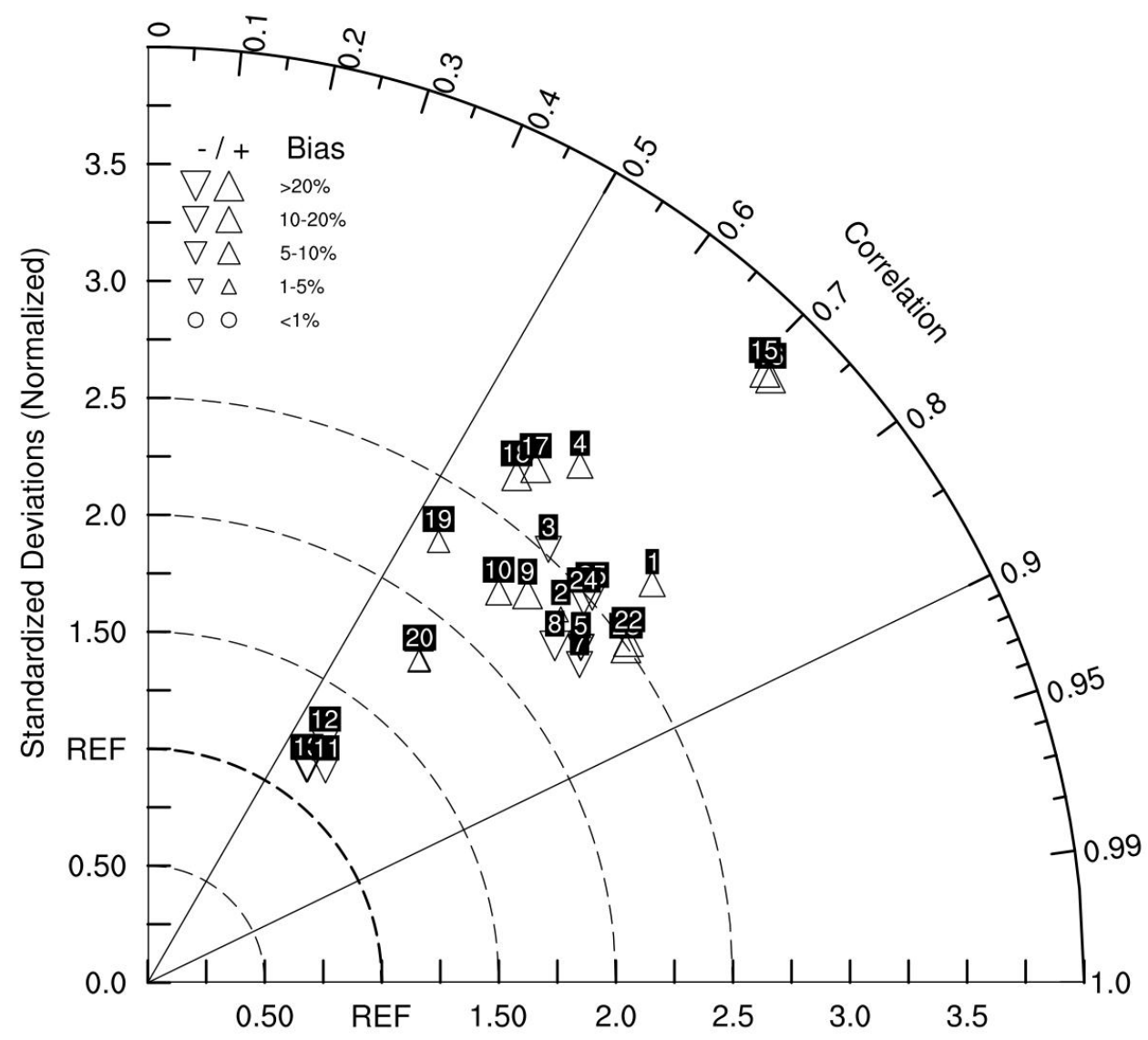

Figure 3: Taylor plot of model heterotrophic respiration (RH) bias, normalized rootmean-square (RMS) differences and global spatial correlation as compared to observed RH (Hashimoto et al. 2015). Model data and observations were temporally averaged over the 1950-1999 period; a weighted area sum $\left(80^{\circ} \mathrm{N}-60^{\circ} \mathrm{S}\right)$ was done for models and observations. 
Biogeosciences Discuss., https://doi.org/10.5194/bg-2017-405

Manuscript under review for journal Biogeosciences

Discussion started: 12 October 2017

(c) Author(s) 2017. CC BY 4.0 License.

\section{(c) (i)}
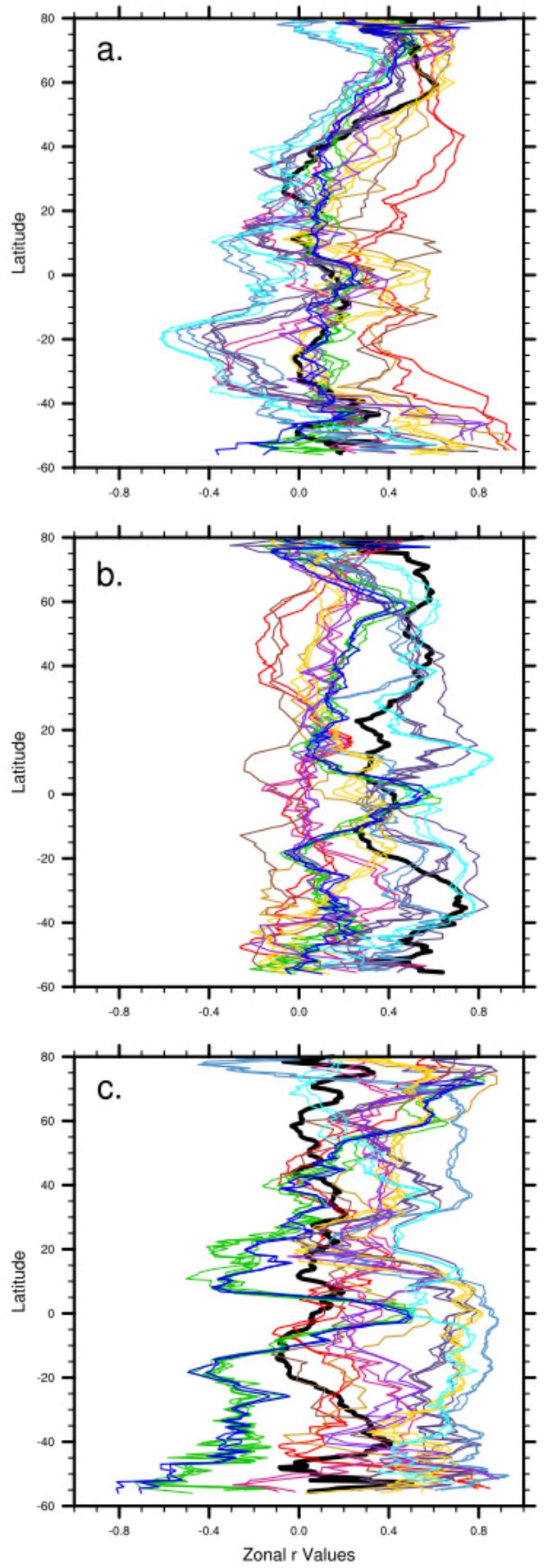
Figure 4. Pearson correlation coefficient $(r)$ between historical annual heterotrophic respiration $(\mathrm{RH})$ and surface temperature (TAS, a), precipitation flux (PR, b), and net primary production $(\mathrm{NPP}, \mathrm{c})$ by latitude. Correlation values were calculated at each grid cell from annual RH and TAS. Black line is the observed RH and TAS (a, 1948-2010), PR (b, 1979-2010), and NPP (c, 2000-2013) $r$ values. Line colors correspond to models from same modeling center and are $r$ values for the years 1900-2005. Line colors are consistent with Figure 2.
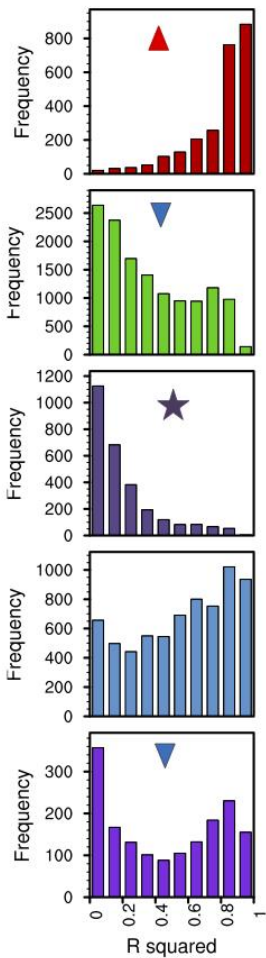
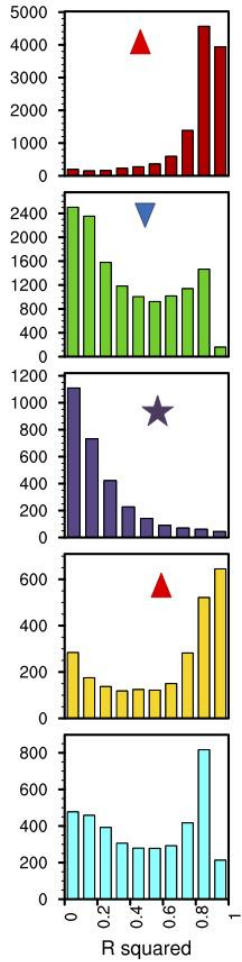
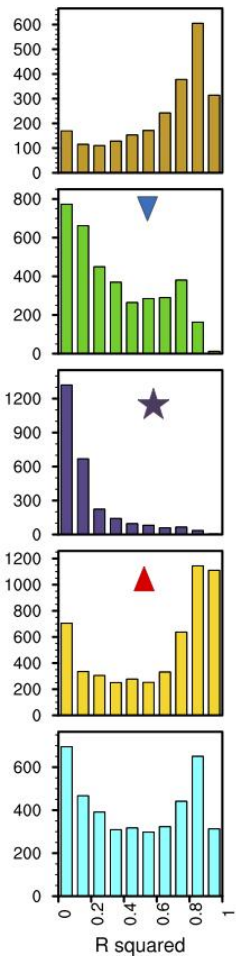
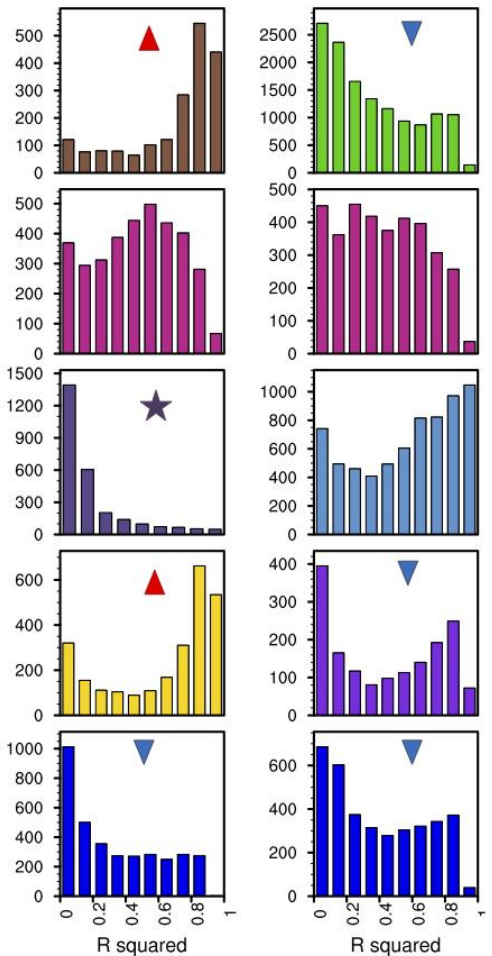
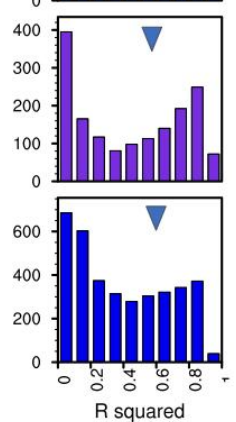

Figure 5: Histograms of grid cell $\mathrm{R}^{2}$ values for the relationship between local and global heterotrophic respiration for RCP 8.5 scenario (2006-2099). Models were grouped by average $R^{2}$ into strong relationship (average $R^{2} \geq 0.75$, red triangles), weak relationship (average $\mathrm{R}^{2} \leq 0.25$, blue triangles), and the GISS-E2 models (dark purple stars). Color of histograms correspond to models from same modeling center. Only values between $80^{\circ} \mathrm{N}$ and $60^{\circ} \mathrm{S}$ are displayed. 
Biogeosciences Discuss., https://doi.org/10.5194/bg-2017-405

Manuscript under review for journal Biogeosciences

Discussion started: 12 October 2017

(c) Author(s) 2017. CC BY 4.0 License.

(c) (1)
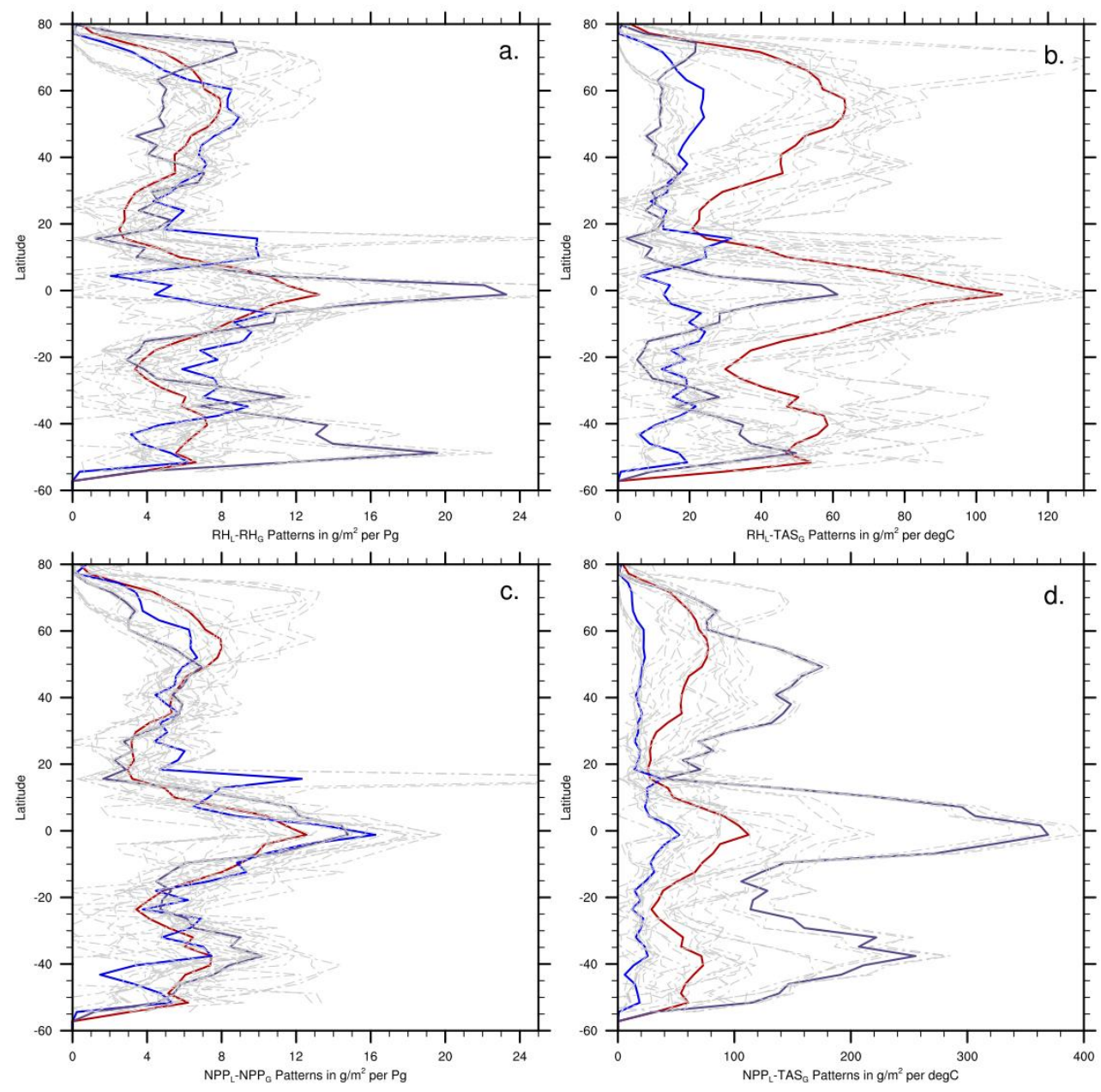

Figure 6. Patterns of local-global heterotrophic respiration $\left(\mathrm{RH}_{\mathrm{L}}-\mathrm{RH}_{\mathrm{G}} ; \mathrm{a}\right), \mathrm{RH}_{\mathrm{L}}$ and global temperature $\left(\mathrm{TAS}_{\mathrm{G}} ; \mathrm{b}\right)$, local-global net primary productivity $\left(\mathrm{NPP}_{\mathrm{L}}-\mathrm{NPP}_{\mathrm{G}} ; \mathrm{c}\right)$, and $\mathrm{NPP}_{\mathrm{L}}-$

$5 \mathrm{TAS}_{\mathrm{G}}$ (d) for RCP 8.5 scenario (2006-2099). Models were grouped by average $\mathrm{R}^{2}$ into strong relationship (average $R^{2} \geq 0.75$, red line), weak relationship (average $R^{2} \leq 0.25$, blue line), and the GISS-E2 models (dark purple line). Gray dashed lines are the patterns from each ensemble member. Only values between $80^{\circ} \mathrm{N}$ and $60^{\circ} \mathrm{S}$ are displayed. 
Biogeosciences Discuss., https://doi.org/10.5194/bg-2017-405

Manuscript under review for journal Biogeosciences

Discussion started: 12 October 2017

(c) Author(s) 2017. CC BY 4.0 License.
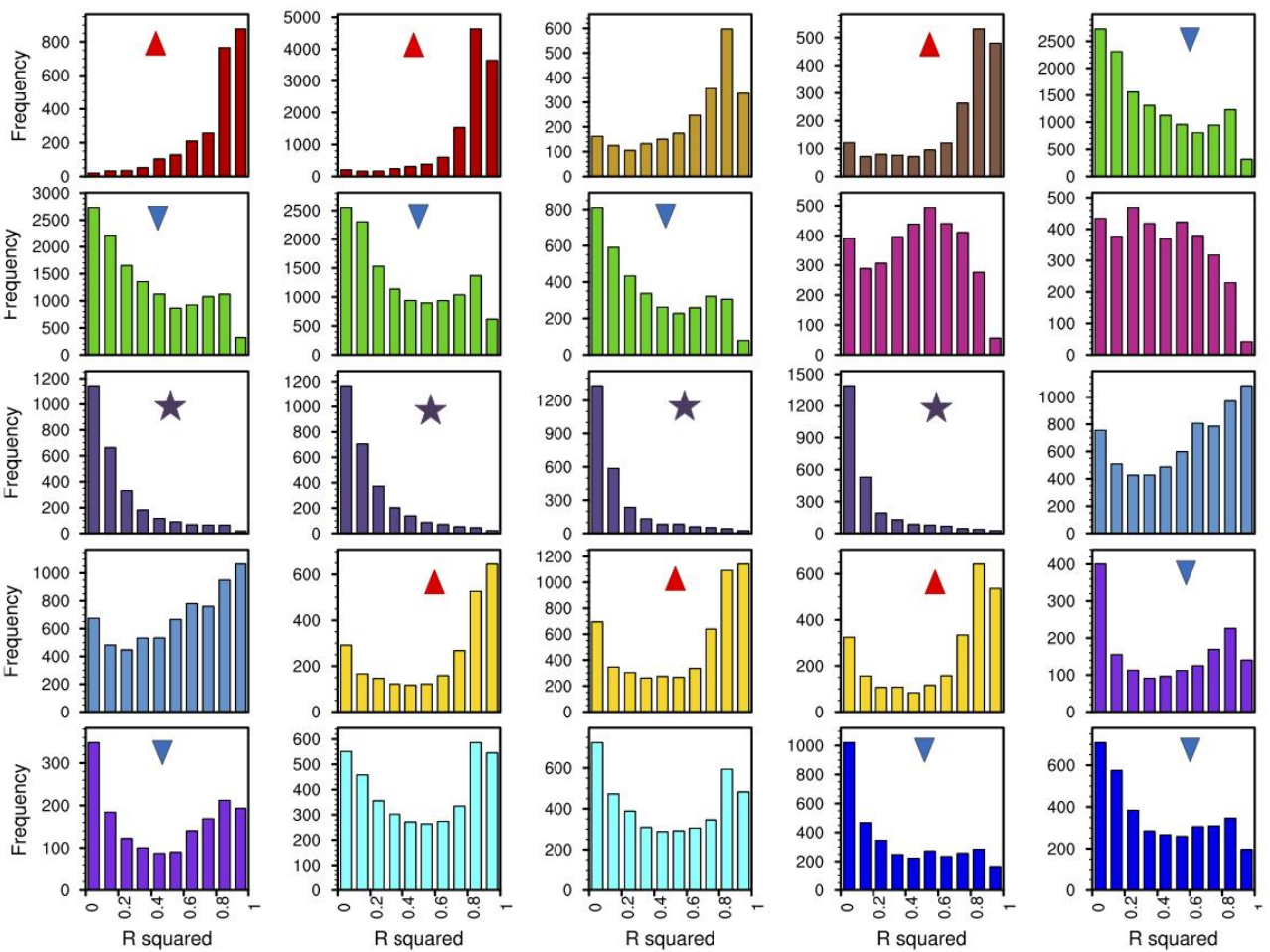

Figure 7. Histograms of grid cell $\mathrm{R}^{2}$ values for the relationship between local heterotrophic respiration and global surface temperature $\left(\mathrm{RH}_{\mathrm{L}}-\mathrm{TAS}_{\mathrm{G}}\right)$ for RCP 8.5 scenario (2006-2099). Histogram colors and groupings are the same as in Figure 5. 
Biogeosciences Discuss., https://doi.org/10.5194/bg-2017-405

Manuscript under review for journal Biogeosciences

Discussion started: 12 October 2017

(C) Author(s) 2017. CC BY 4.0 License.
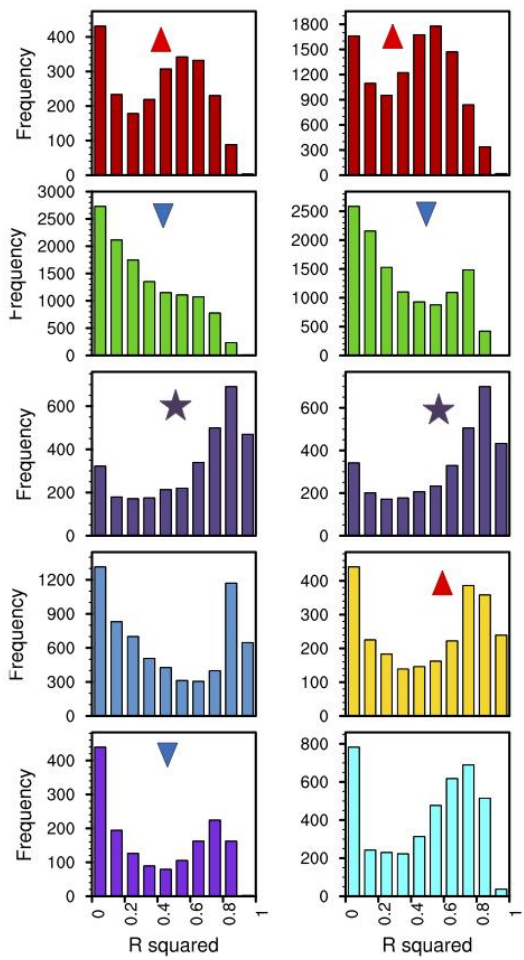
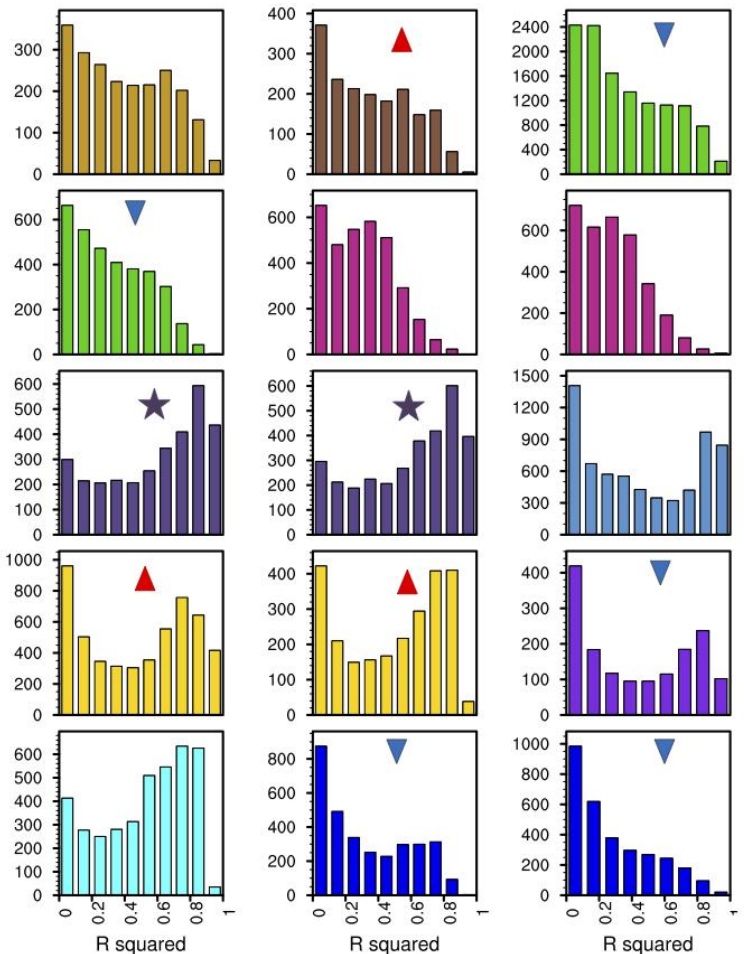

Figure 8: Histograms of grid cell $\mathrm{R}^{2}$ values for the relationship between local and global net primary production $\left(\mathrm{NPP}_{\mathrm{L}}-\mathrm{NPP}_{\mathrm{G}}\right)$ for RCP 8.5 scenario (2006-2099). Histogram colors and groupings are the same as Figure 5. 
Biogeosciences Discuss., https://doi.org/10.5194/bg-2017-405

Manuscript under review for journal Biogeosciences

Discussion started: 12 October 2017
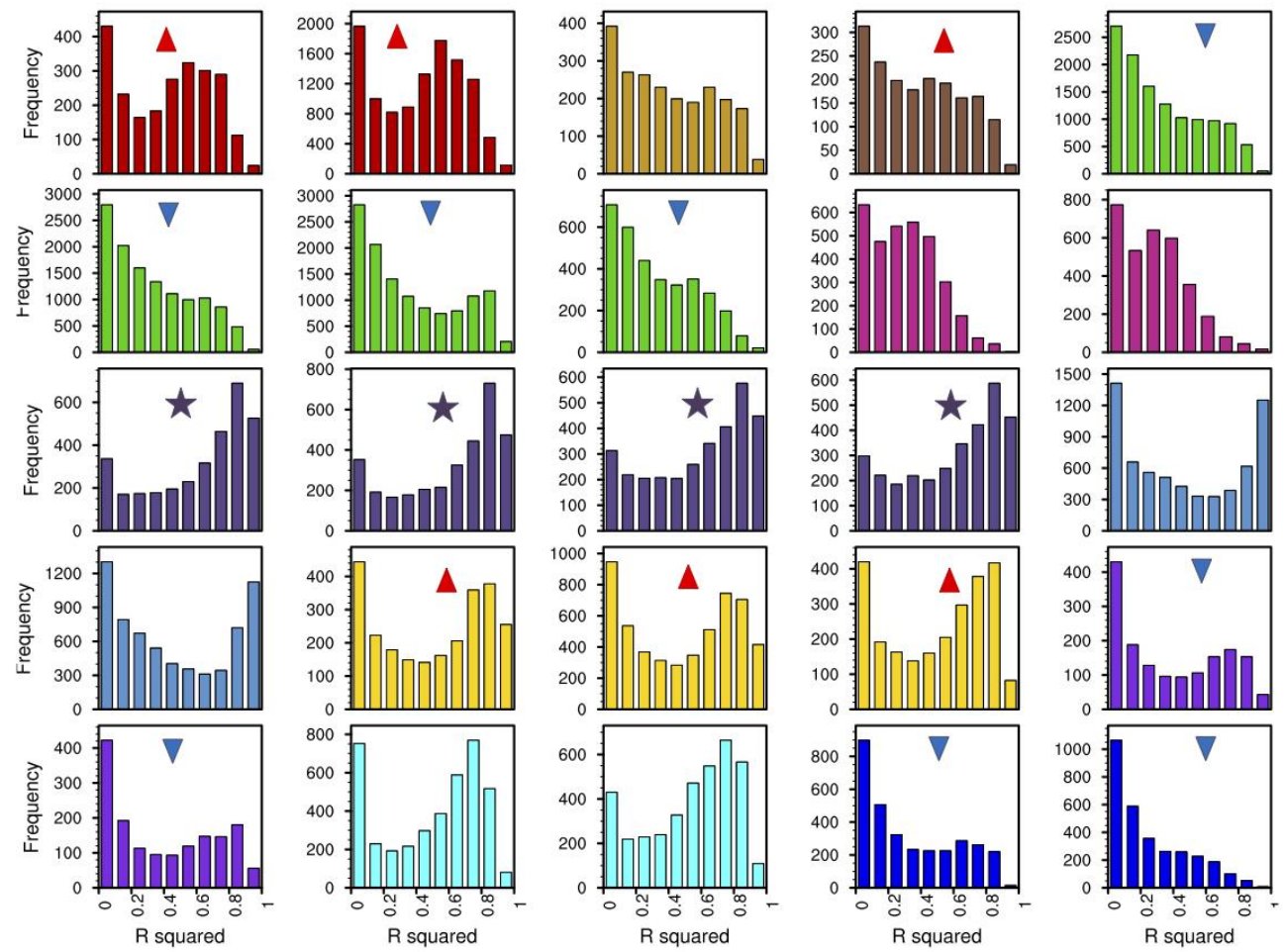

Figure 9: Histograms of grid cell $\mathrm{R}^{2}$ values for the relationship between local net primary production and global surface temperature $\left(\mathrm{NPP}_{\mathrm{L}}-\mathrm{TAS}_{\mathrm{G}}\right)$ for RCP 8.5 scenario (20062099). Histogram colors and groupings are the same as Figure 5. 
Biogeosciences Discuss., https://doi.org/10.5194/bg-2017-405

Manuscript under review for journal Biogeosciences

Discussion started: 12 October 2017

(c) Author(s) 2017. CC BY 4.0 License.

\section{a.}
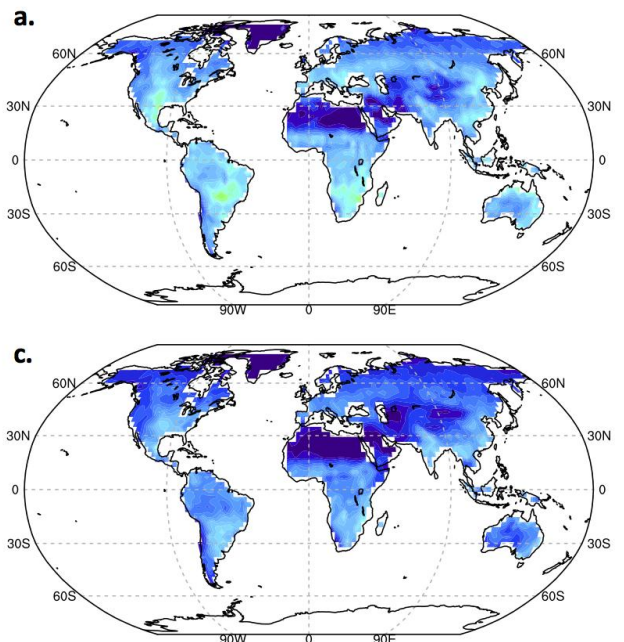
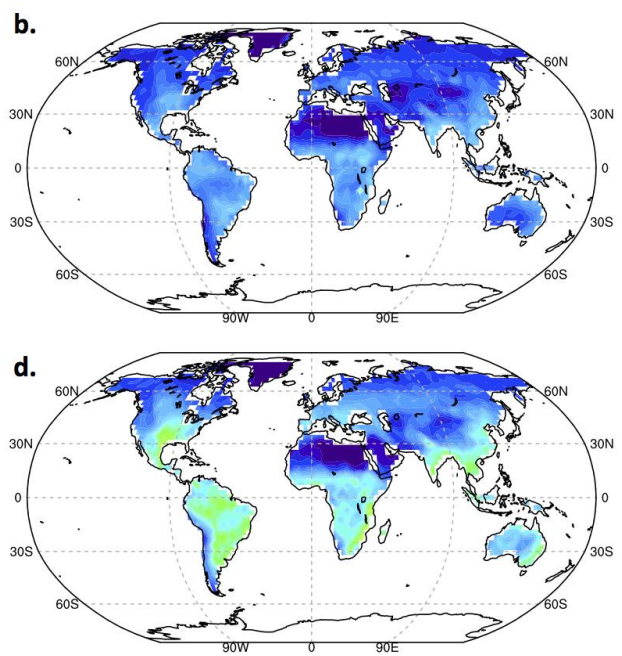

-

Figure 10: Multi-model ensemble average of the standard error of the estimated pattern for local-global heterotrophic respiration $\left(\mathrm{RH}_{\mathrm{L}}-\mathrm{RH}_{\mathrm{G}}\right.$ in $\mathrm{g} / \mathrm{m}^{2}$ per $\mathrm{Pg}$; a), local $\mathrm{RH}$ and global surface temperature $\left(\mathrm{RH}_{\mathrm{L}}-\mathrm{TAS}_{\mathrm{G}}\right.$ in $\mathrm{g} / \mathrm{m}^{2}$ per ${ }^{\circ} \mathrm{C}$; b), local $\mathrm{RH}$ and global net primary production $\left(\mathrm{RH}_{\mathrm{L}}-\mathrm{NPP}_{\mathrm{G}}\right.$ in $\mathrm{g} / \mathrm{m}^{2}$ per $\left.\mathrm{Pg} ; \mathrm{c}\right)$, and local-global net primary production $\left(\mathrm{NPP}_{\mathrm{L}}-\mathrm{NPP}_{\mathrm{G}}\right.$ in $\mathrm{g} / \mathrm{m}^{2}$ per Pg; d) over $21^{\text {st }}$ century from the RCP 8.5 scenario. 